\title{
Donor lymphocyte infusions for the treatment of minimal residual disease in acute leukemia
}

\author{
Infusão de linfócitos do doador para o tratamento da doença residual mínima
}

\author{
Andrea Bacigalupo \\ Alida Dominietto \\ Sarah Pozzi \\ Maurizio Miglino \\ Flavio Albarracin \\ Giovanna Piaggio \\ Francesca Bertolotti
}

\begin{abstract}
Minimal residual disease (MRD) was monitored in 80 patients with acute lymphoid (ALL, $n=44)$ or myeloid ( $A M L, n=36)$ leukemia, undergoing allogeneic haemopoietic stem cell transplantations. MRD markers were IgH-VDJ and TCR gene rearrangement for ALL, and Wilm's Tumor (WT1) expression for AML. The overall cumulative incidence (CI) of MRD was positive in $45 \%$ and the CI of hematologic relapse was $24 \%$ (36\% in MRD $+v$ s. $16 \%$ in MRD patients, $p=0.03)$. The median interval from transplant to first MRD positivity was 120 days and to hematologic relapse 203 days. Patients were divided in 3 MRD groups: MRD $(n=44), M R D+$ given donor lymphocyte infusions (DLI) $(n=17)$ and MRD + not given DLI $(n=19)$ : leukemia relapse rates in these 3 groups were $16 \%, 6 \%$ and $63 \%$, respectively $(p<0.0001)$; the actuarial 3-year survival rates were $78 \%, 80 \%$ and $26 \%(p=0.001)$. In multivariate COX analysis, the MRD group was predictor of relapse $(p<0.0001)$ and survival $(p=0.01)$, together with disease phase and chronic graft versus host disease. In MRD+ patients, DLI protected against relapse $(p=0.003)$ and improved survival $(p=0.01)$. In conclusion, MRD positivity post-transplant predicts leukemia relapse: however, when $M R D+$ patients are given $D L I$, their outcomes are comparable to MRD-patients. Rev. bras. hematol. hemoter. 2008;30(Supl. 2):42-44.
\end{abstract}

Key words: Minimal residual disease; acute myeloid leukemia; acute lymphoid leukemia; donor lymphocyte infusion; allogeneic hematopoietic stem cell transplantation.
Hematologic relapse after an allogeneic hemopoietic stem cell transplant (HSCT) in patients with acute leukemia is associated with a poor outcome, despite further cell therapy in the form of donor lymphocyte infusions (DLI). ${ }^{1}$ This has been taken as evidence that acute leukemia is less sensitive to the so called graft versus leukemia (GvL) effect, especially if compared with chronic myeloid leukemia (CML), in which DLI alone can induce durable long term molecular remissions. ${ }^{2}$ However, several reports suggest a strong protection exerted by chronic graft versus host disease (GvHD) in acute lymphoid (ALL) and myeloid (AML) leukemia, ${ }^{3,4}$ and low dose immunosuppression in the first days after transplant also reduces the risk of relapse. ${ }^{5,6}$
Perhaps DLI would be effective in ALL and AML patients, if given when the tumor burden is low. Attempts to monitor minimal residual disease (MRD) in acute leukemia post-HSCT have been reported and seem to predict hematologic relapse. ${ }^{7,8}$ Some of these patients were given immune intervention to prevent hematologic relapse. ${ }^{9}$

In this study we wished to assess (a) the predictive value of MRD on hematologic relapse post-transplant in AML/ALL patients and (b) whether cellular therapy with DLI would protect against leukemia relapse. We studied 80 patients with ALL $(n=44)$ or AML $(n=36)$, undergoing an allogeneic hemopoietic stem cell transplant. MRD was evaluated monthly, on bone marrow samples using a

Divisione di Ematologia e Trapianto di Midollo Osseo, Ospedale San Martino, Genova, Italy.

Correspondence: Andrea Bacigalupo

Divisione Ematologia e Trapianto di Midollo Osseo, Ospedale San Martino, Genova, Italy

Ospedale San Martino Largo Rosanna Benzi 10

16132 - Genova, Italy

Phone: +39010355469 Fax: +39010355583

E-mail: andrea.bacigalupo@hsanmartino.it 
qualitative nested polymerase chain reaction (PCR) for IgH VDJ , as previously described ${ }^{10}$ and TCR gene rearrangement for T-ALL. Real time PCR for Wilms Tumour (WT1) expression was used in AML. ${ }^{11}$ MRD was considered positive in AML when WT1 copy numbers every 104 copies of Abl were superior to 180 . Molecular positivity was defined as a positive PCR assay, in the presence of a marrow sample in hematologic remission (blast count $<5 \%$ ).

The cumulative incidence of MRD positivity was $45 \%$, with a median interval from transplant to first MRD positivity of 120 days, and from transplant to hematologic relapse of 203 days. Hematologic relapse was significantly higher in MRD + patients (36\%) as compared to MRD- patients (16\%), $\mathrm{p}=0.03$ ). Patients were analyzed according to whether they were always MRD- $(n=44), M R D+$ receiving DLI $(\mathrm{MRD}+\mathrm{DLI}+)(\mathrm{n}=17)$ or $\mathrm{MRD}+$ non receiving DLI (MRD+DLI-) $(\mathrm{n}=19)$. Reasons for not giving DLI were presence or development of GvHD after cessation of immunosuppressive therapy $(\mathrm{n}=7)$, donor unavailable $(\mathrm{n}=8)$, early relapse $(n=2)$, other $(n=2)$. Hematologic relapse was $16 \%$ in MRD-patients, $6 \%$ in MRD+DLI+ patients and $63 \%$ in MRD+DLI- patients $(\mathrm{p}<0.0001)$; the actuarial 3 year survival in these three groups was $78 \%, 80 \%$ and $26 \%$ $(p=0.001)$. Mortality due to acute GvHD following DLI was $12 \%$. In multivariate COX analysis, MRD group predicted relapse $(p<0.0001)$ and survival $(p=0.01)$, together with disease phase and chronic graft versus host disease. In $\mathrm{MRD}+$ patients, DLI protected against relapse $(\mathrm{p}=0.003)$ and improved survival $(\mathrm{p}=0.01)$.

In conclusion, we confirm that minimal residual disease detected post-transplant is a significant predictor of relapse. Treatment of MRD with donor lymphocyte infusions, appears to protect against leukemia relapse, although caution with DLI dosing, needs to be used, because of the potential risk of graft versus host disease.

\section{Resumo}

A doença residual mínima (DRM) foi monitorada em 80 pacientes com leucemia linfóide aguda $(n=44)$ e mielóide aguda $(n=36)$ que foram submetidos ao transplante alogênico de célula-tronco. Marcadores da DRM foram a IgH-VDJ e rearranjo do TCR para a LLA e expressão do Tumor de Wills (WT1) para LMA. A incidência acumulada global (IC) para a DRM foi positiva em $45 \%$ e a IC para recaida hematológica foi $24 \%$ (36\% na DRM+ versus $16 \%$ na DRM-, $p=0.03)$. O intervalo mediano entre o TMO e a primeira DRM positividade foi dia +120 , e para a recaída hematológica, dia +203 . Os pacientes puderam ser divididos em três grupos: DRM- $(n=44), D R M+$ onde foi dada a infusão de linfócitos do doador (ILD) $(n=17)$ e DRM+ não dado ILD $(n=19)$ : a recidiva nos três grupos foi de $16 \%, 6 \%$ e $63 \%$, respectivamente $(p<0.0001)$; a sobrevida em três anos foi $78 \%$, $80 \%$ e $26 \%$ ( $p=0.001)$. No modelo de Cox, o grupo de DRM foi preditor de recidiva $(p<0.0001)$ e sobrevida global $(p=0.01)$, juntamente com a fase da doença e a doença do enxerto contra o hospedeiro. $\mathrm{Na} D \mathrm{RM}+$, IDL protegeu contra a recidiva $(p=0.003)$ e melhorou a sobrevida ( $p=0.01)$. Em conclusão, a positividade para a DRM pós-transplante prediz recidiva da leucemia. Entretanto, quando é dada a ILD ao paciente DRM+, a evolução destes pacientes é comparável aos pacientes DRM-. Rev. bras. hematol. hemoter. 2008;30(Supl. 2):42-44.

Palavras-chave: Doença residual mínima; leucemia mielóide aguda; leucemia linfóide aguda; infusão de linfócitos total; transplante alogênico de células-tronco hematopoéticas.

\section{References}

1. Kolb HJ, Schattenberg A, Goldman JM, Hertenstein B, Jacobsen N, Arcese W, et al; European Group for Blood and Marrow Transplantation Working Party Chronic Leukemia. Graft-versusleukemia effect of donor lymphocyte transfusions in marrow grafted patients. Blood. 1995;86(5):2041-50.

2. Weisser M, Tischer J, Schnittger S, Schoch C, Ledderose G, Kolb HJ. A comparison of donor lymphocyte infusions or imatinib mesylate for patients with chronic myelogenous leukemia who have relapsed after allogeneic stem cell transplantation. Haematologica. 2006;91:663-6.

3. Weiden PL, Sullivan KM, Flournoy N, Storb R, Thomas ED. Antileukemic effect of chronic graft-versus-host disease: contribution to improved survival after allogeneic marrow transplantation. N Engl J Med. 1981;304(25):1529-33.

4. Sullivan KM, Weiden PL, Storb R, Witherspoon RP, Fefer A, Fisher L, et al. Influence of acute and chronic graft-versus-host disease on relapse and survival after bone marrow transplantation from HLA-identical siblings as treatment of acute and chronic leukemia. Blood. 1989;73:1720-8.

5. Bacigalupo A, van Lint MT, Occhini D, Gualandi F, Lamperelli T, Sogno G, et al. Increased risk of leukemia relapse with high-dose cyclosporine A after allogeneic marrow transplantation for acute leukemia. Blood. 1991;77:1423-28.

6. Locatelli F, Zecca M, Rondelli R, Bonetti F, Dini G, Prete A, et al. Graft versus host disease prophylaxis with low-dose cyclosporine-A reduces the risk of relapse in children with acute leukemia given HLA-identical sibling bone marrow transplantation: results of a randomized trial. Blood. 2000; 95(5):1572-9.

7. Uzunel M, Jaksch M, Mattsson J, Ringden O. Minimal residual disease detection after allogeneic stem cell transplantation is correlated to relapse in patients with acute lymphoblastic leukaemia. Br J Haematol. 2003;122(5):788-94.

8. Ogawa H, Tamaki H, Ikegame K, Soma T, Kawakami M, Tsuboi A, et al. The usefulness of monitoring WT1 gene transcripts for the prediction and management of relapse following allogeneic stem cell transplantation in acute type leukemia. Blood. 2003;101(5):1698-704. Epub 2002 Oct 24.

9. Bader P, Kreyenberg H, Hoelle W, Dueckers G, Handgretinger R, Lang $\mathrm{P}$, et al. Increasing mixed chimerism is an important prognostic factor for unfavourable outcome in children with acute lymphoblastic leukemia after allogeneic stem-cell transplantation: possible role for pre-emptive immunotherapy? J Clin Oncol. 2004;22(9):1696-705.

10. Miglino M, Berisso G, Grasso R, Canepa L, Clavio M, Pierri I, et al. Allogeneic bone marrow transplantation (BMT) for adults with acute lymphoblastic leukemia (ALL): predictive role of minimal residual disease monitoring on relapse. Bone Marrow Transplant. 2002;30:579-85. 
11. van Dongen JJ, Macintyre EA, Gabert JA, Delabesse E, Rossi V, Saglio G, et al. Standardized RT-PCR analysis of fusion gene transcripts from chromosome aberrations in acute leukaemia for detection of minimal residual disease. Report of the BIOMED-1 concerted action: investigation of minimal residual disease in acute leukaemia. Leukemia. 1999;13:1901-28.

This work was partly supported by Associazione Italiana Ricerca contro il Cancro (A.I.R.C.) Milano, Foundation FA-RITMO and CARIGE Genova.

O tema apresentado constou do programa do Encontro AIBE. Avaliadores: Professores Ângelo Maiolino, Cármino Antonio de Souza e Marcio Nucci.

Publicado após concordância do editor.

Conflito de interesse: não declarado.

Recebido: $13 / 05 / 2008$

Aceito: $13 / 05 / 2008$ 